\title{
TEMPERATURE DISTRIBUTION IN THE UPPER LAYERS OF THE ABLATION AREA OF ATHABASCA GLACIER, ALBERTA, CANADA
}

\author{
W. S. B. Paterson \\ (Polar Continental Shelf Project, Department of Energy, Mines and Resources, Ottawa, \\ Ontario, Canada)
}

\begin{abstract}
Ten-meter temperature measurements show that Athabasca Glacier is temperate in the accumulation area but not in the ablation area. An important factor in determining whether all the ice will reach a temperature of $\mathrm{o}^{\circ} \mathrm{C}$ by the end of summer is how much of the layer of ice, cooled during the previous winter, is removed by ablation. However, calculations show that, even when allowance is made for ablation, not enough heat is conducted into the ice to bring it all to the melting point. As recent work suggests that ice at $o^{\circ} \mathrm{C}$ is permeable to water, latent heat released by refreezing of percolating melt water is considered; it appears likely that this process is an insignificant heat source in the ablation area. Available data show that the penetration of solar radiation can probably also be neglected. The question of how widespread temperate glaciers are is discussed; it is predicted that in most, if not all, glaciers there is a region below the equilibrium line where, because ablation is low, the glacier is not strictly temperate.
\end{abstract}

Résumé. Distribution de température dans les niveaux supérieurs des aires d'ablation du glacier de l'Athabasca, Alberta, Canada. Des mesures de températures sur $10 \mathrm{~m}$ de profondeur montrent que le glacier de l'Athabasca est tempéré dans la zone d'accumulation mais non dans celle d'ablation. Pour savoir si toute la glace atteindra une température de $o^{\circ} \mathrm{C}$ en fin d'été, un facteur important est de connaître quelle partie du niveau de glace refroidie pendant l'hiver précédent est enlevée par l'ablation. Cependant, les calculs montrent que, même en tenant compte de l'ablation, la conduction de chaleur dans la glace n'est pas suffisante pour l'amener dans sa totalité au point de fusion. Parce qu'un récent travail suggère que la glace à $0^{\circ} \mathrm{C}$ est perméable à l'eau, on a considéré la chaleur latente mise en jeu par le regel de l'eau de percolation; il apparait vraisemblable que ce processus est une source de chaleur insignifiante dans la zone d'ablation. Les données disponibles montrent que la pénétration de la radiation solaire peut probablement aussi être négligée. On discute la question de l'extension des glaciers tempérés; on conjecture que dans la plupart, sinon dans tous les glaciers, il existe une région en dessous de la ligne d'équilibre où, parce que l'ablation est faible, le glacier n’est pas strictement tempéré.

Zusammenfassung. Die Temperaturverteilung in den oberen Schichten des Ablationsgebietes am Athabasca Glacier, Alberta, Kanada. Messungen der Temperatur in $10 \mathrm{~m}$ Tiefe zeigen, dass der Athabasca Glacier zwar im Akkumulationsgebiet temperiert ist, nicht aber im Ablationsgebiet. Ein wichtiger Punkt bei der Analyse, ob das gesamte Eis am Ende der Sommers eine Temperatur von $0^{\circ} \mathrm{C}$ erreicht, ist die Frage, wieviel von der während des vorangegangenen Winters abgekühlten Eisschicht durch Ablation abgebaut wurde. Jedoch wird - wie Berechnungen zeigen - selbst mit einem gewissen Spielraum für die Ablation nicht genügend Wärme in das Eis geleitet, um es in seiner Gesamtheit bis zum Schmelzpunkt zu erwärmen. Da neuere Arbeiten vermuten lassen, dass Eis bei $0^{\circ} \mathrm{C}$ wasserdurchlässig ist, wird latente Wärme, die beim Gefrieren durchsickernden Schmelzwassers frei wird, in Betracht gezogen; dieser Vorgang scheint jedoch nur eine unbedeutende Wärmequelle im Ablationsgebiet zu sein. Verfügbare Daten zeigen, dass das Eindringen der Sonnenstrahlung wahrscheinlich ebenfalls vernachlässigt werden kann. Die Frage, wie weit temperierte Gletscher verbreitet sind, wird diskutiert; es wird vorausgesagt, dass es in den meisten, wenn nicht allen Gletschern ein Gebiet unterhalb der Gleichgewichtslinie gibt, in dem infolge geringer Ablation der Gletscher nicht streng temperiert ist.

\section{Introduction}

In a "temperate" glacier, as usually defined, all the ice is at the pressure melting point except for a near-surface layer, some $\mathrm{s}$ o $\mathrm{m}$ thick, whose temperature is below $\mathrm{o}^{\circ} \mathrm{C}$ in winter (Ahlmann, 1935). The name arises because such glaciers are found mainly in temperate regions; but not all glaciers in these regions are of this type. For example, sub-freezing temperatures have been measured, at depths below the limit of seasonal variations, in the ice cap at the Jungfraujoch and on Mont Blanc, Breithorn and Monte Rosa in the Alps (Vallot, I913; Hughes and Seligman, I939; Fisher, 1955, I963), in Vesl-Skautbreen in Norway (McCall, I952), in Lednik Tsentral'nyy Tuyuksu in the Tien Shan, U.S.S.R. (Vilesov, 196r), in Taku Glacier in southern Alaska (Miller, [1956]), and at the base of South Leduc Glacier in western Canada (Mathews, 1964). Again, Schytt (1968) measured 
temperatures below $0^{\circ} \mathrm{C}$ in Stor Glaciären in Swedish Lappland which, though north of the Arctic circle, had previously been considered temperate. How widespread temperate glaciers are thus remains uncertain.

For a glacier to be temperate, the whole of the layer that is cooled in winter must be brought to $0^{\circ} \mathrm{C}$ during the following summer. In the accumulation area, heat transfer from the surface to the underlying firn has been studied in detail by Sverdrup (1935), Hughes and Seligman (I939), Sharp (195I), and others. They found that, once surface melting begins, the dominant factor in warming the firn is latent heat released when percolating melt water refreezes on contact with a sub-freezing layer. In the ablation area, however, latent heat is much less important because ice is, at best, only slightly permeable to water. As a result, ice may be warmer in the accumulation area than in the ablation area. Paterson (i969, p. I75) has quoted some examples of this. In particular, some glaciers may be temperate only in the accumulation area (Loewe, i966; Schytt, i968, r969).

In comparison with the detailed studies made in the accumulation area, heat transfer from the surface to the underlying layers in the ablation area seems to have received less attention. A discussion of this question, based on data from Athabasca Glacier, forms the subject of this paper.

\section{Athabasca Glacier}

Athabasca Glacier (lat. $52.2^{\circ}$ N., long. $117.2^{\circ} \mathrm{W}$.) is one of the main outlet glaciers from the Columbia Icefield in the Canadian Rocky Mountains. The Icefield lies on the continental divide some $700 \mathrm{~km}$ from the Pacific Ocean. Table I contains data for the two nearest weather stations. Figure I shows the glacier; Paterson and Savage (rg63) have described it in detail. The equilibrium line usually lies at an elevation of about $2600 \mathrm{~m}$ in the highest of three ice falls by which the glacier descends from the Icefield. Snow pits,

Table I. Climatic data for the two stations nearest to Athabasca Glacier

\begin{tabular}{lcc}
\multicolumn{1}{c}{ Name } & Jasper & Lake Louise \\
Distance from glacier $(\mathrm{km})$ & 90 & I Io \\
Direction from glacier & N.W. & S.E. \\
Elevation $(\mathrm{m})$ & $\mathrm{I}$ o6 $\mathrm{I}$ & $\mathrm{I} 534$ \\
Annual precipitation $(\mathrm{m})$ & $0.4 \mathrm{I}$ & $0.8 \mathrm{I}$ \\
Mean annual temperature $\left({ }^{\circ} \mathrm{C}\right)$ & +3 & $-\mathrm{I}$ \\
Mean January temperature $\left({ }^{\circ} \mathrm{C}\right)$ & $-\mathrm{I} \mathrm{I}$ & $-\mathrm{I} 5$ \\
Mean July temperature $\left({ }^{\circ} \mathrm{C}\right)$ & $+\mathrm{I} 5$ & $+\mathrm{I} 2$
\end{tabular}

dug in the ablation area in late April, reveal no sign of melting during the winter and indicate that the winter precipitation is equivalent to roughly $\mathrm{I} \mathrm{m}$ of water. In most years, the entire snow cover in the region, $3.8 \mathrm{~km}$ long, between the foot of the lowest ice fall and the terminus reaches a temperature of $0^{\circ} \mathrm{C}$ in late June; the ice becomes free of snow in the first half of July and the ablation season ends in the first half of September. About $3.8 \mathrm{~m}$ of ice is lost annually from this section; the amount varies little from place to place except near the terminus and in moraine-covered areas near the valley walls.

\section{Temperature measurements}

Temperatures were measured by thermistors in holes, Io $\mathrm{m}$ deep, made with a hand drill. Resistance was measured to the nearest Io $\Omega$ which corresponds to $0.04 \mathrm{deg}$. Figure I shows the positions of the holes. Table II lists ro-meter temperatures in all holes except hole $\mathrm{F}$ which punctured a water-filled cavity at a depth of $9.2 \mathrm{~m}$ (Paterson and Savage, 


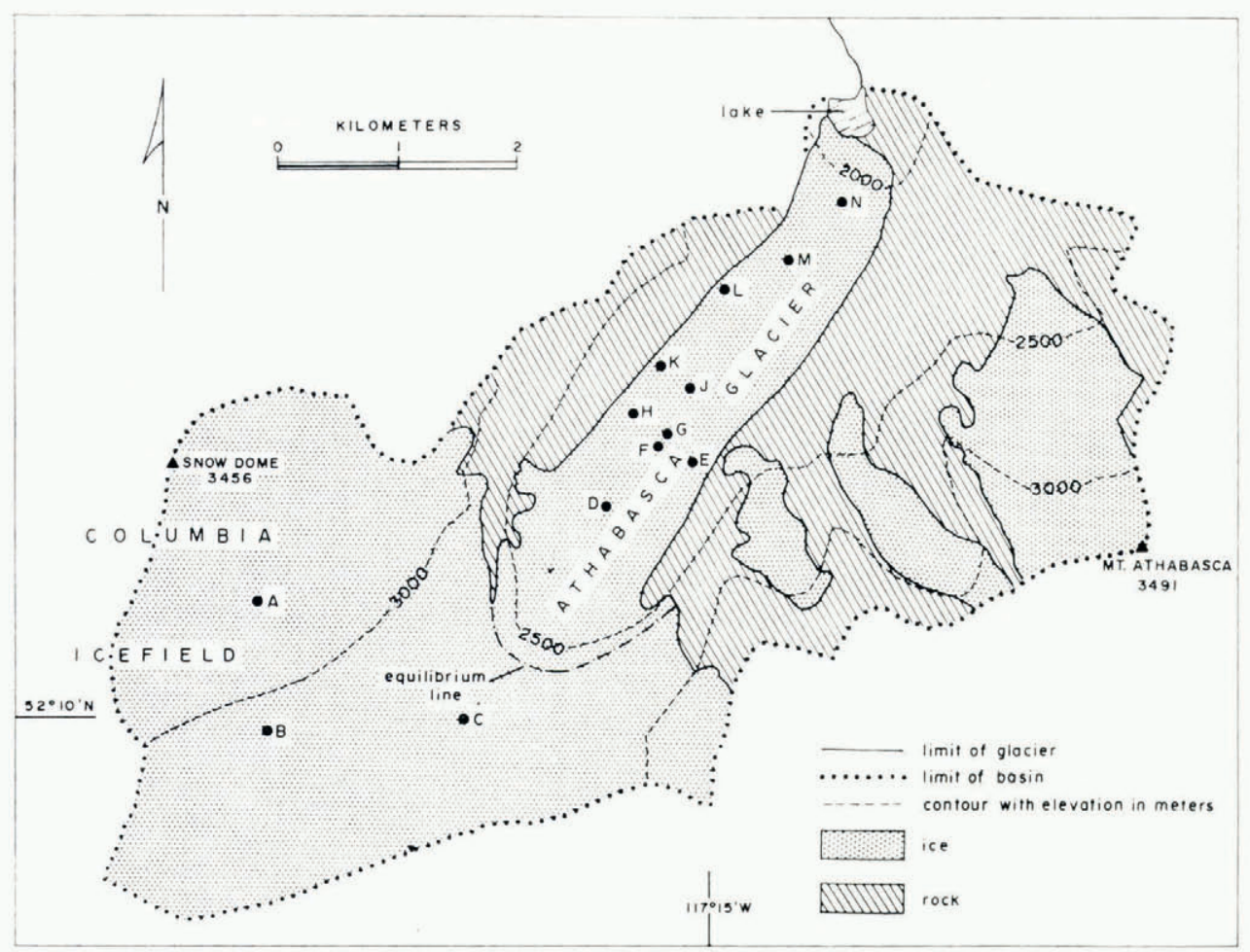

Fig. I. Map of Athabasca Glacier showing locations of Io-meter bore holes.

Table II. Ten-meter temperatures in Athabasca Glacier

(Holes A, B, C are in accumulation area, others in ablation area)

$\begin{array}{cccc}\text { Hole } & \begin{array}{c}\text { Elevation } \\ \mathrm{m}\end{array} & \text { Date } & \begin{array}{c}\text { Temperature } \\ { }^{\circ} \mathrm{C}\end{array} \\ \mathrm{A} & 3200 & \text { 18 August } 1967 & 0 \\ \mathrm{~B} & 2910 & \text { 18 August } 1967 & 0 \\ \mathrm{C} & 2730 & \text { 18 August } 1967 & 0 \\ \mathrm{D} & 2275 & \text { 22 September } 1970 & -0.68 \\ \mathrm{E} & 2235 & 25 \text { April } 1968 & -0.53 \\ \mathrm{G} & 2230 & \text { 21 August } 1967 & -0.41 \\ \mathrm{H} & 2230 & 24 \text { April } 1968 & -0.61 \\ \mathrm{~L} & 2170 & \text { 22 September } 1970 & -1.50 \\ \mathrm{M} & 2115 & 26 \text { April } 1968 & -0.36 \\ \mathrm{~N} & 2065 & \text { 22 September } 1970 & -0.05\end{array}$

I970), hole $\mathrm{J}$ into which water penetrated from the surface, and hole $\mathrm{K}$ which was only $5.2 \mathrm{~m}$ deep. In some holes, temperatures were measured at various depths down to io $\mathrm{m}$. Figure 2 shows temperatures in late April r 968, about the time of maximum winter cooling. Figure 3 shows temperatures in September 1970 at the end of an exceptionally heavy ablation season (about $5 \mathrm{~m}$ compared with an average of $3.8 \mathrm{~m}$ ); ablation had ended by then, air temperature was below $0^{\circ} \mathrm{C}$ and there was up to $0.5 \mathrm{~m}$ of fresh snow on the glacier. We defer discussion of these observations until we have considered the ways in which ice below the surface may receive heat in summer. 


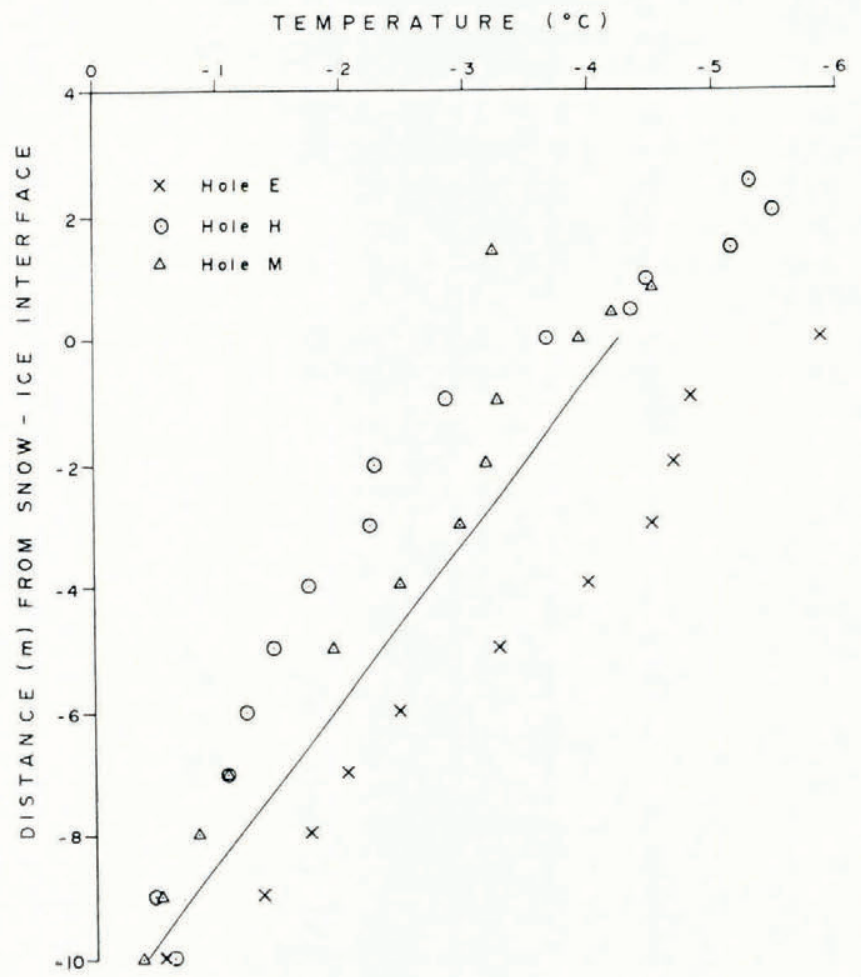

Fig. 2. Snow and ice temperatures measured in three bore holes in late April 1968, and regression line (Equation (3)) fitted to the ice temperatures. The top point in each hole was at the surface.

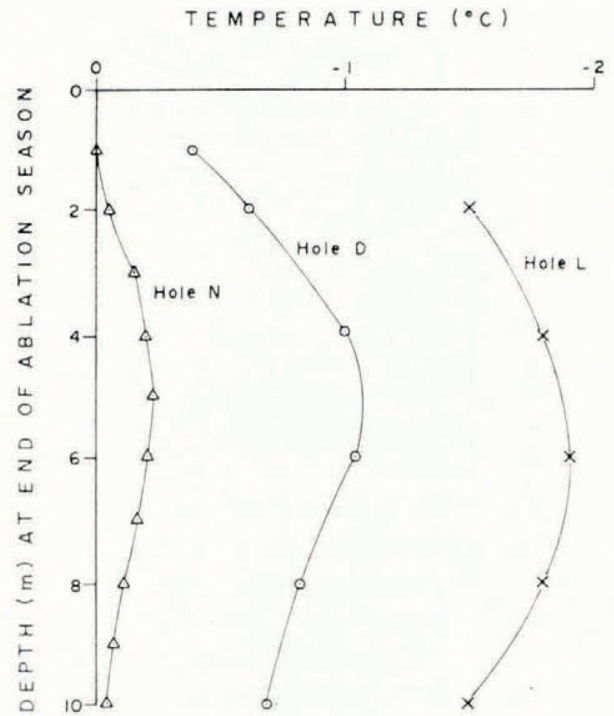

Fig. 3. Ice temperatures measured in three bore holes on 22 September 1970. 


\section{Conduction and ablation}

An appropriate mathematical model is that of heat conduction in a moving semi-infinite medium. To consider a slab of finite thickness would be preferable, but for this case the equation has no analytical solution. Benfield (I95I, I953) has used the same model to study how accumulation affects temperatures in a snowfield.

Let $T$ denote temperature, $t$ time, $y$ depth below surface and $k$ thermal diffusivity. The region $y>0$ moves with velocity $v$, negative for the case of ablation because ice moves upwards relative to the surface. The initial temperature is $T_{0}+a y$. From $t=0$ (the start cf the ablation season) the surface $y=0$ is maintained at $T=0$.

The equation of heat transfer is

$$
\partial T / \partial t=k \partial^{2} T / \partial y^{2}-v \partial T / \partial y .
$$

The solution is a special case of that given by Carslaw and Jaeger (1959, p. 388):

Here

$$
\begin{aligned}
T(y, t) & =T_{0}+a(y-v t)-\frac{1}{2} T_{0}\left[\operatorname{erfc} \omega+\exp y^{\prime} \operatorname{erfc} \omega^{\prime}\right]+ \\
& +\frac{1}{2} a\left[(y+v t) \exp y^{\prime} \operatorname{erfc} \omega^{\prime}-(y-v t) \operatorname{erfc} \omega\right] .
\end{aligned}
$$

$$
\begin{aligned}
\omega & =(y-v t) / 2(k t)^{\frac{1}{2}}, \\
\omega^{\prime} & =(y+v t) / 2(k t)^{\frac{1}{2}}, \\
y^{\prime} & =u y / k, \\
\operatorname{erfc} \omega & =2 \pi^{-\frac{1}{2}} \int_{\omega}^{\infty} \exp \left(-z^{2}\right) \mathrm{d} z .
\end{aligned}
$$

We use this solution to determine temperature as a function of depth at the end of the ablation season. We take the regression line fitted to the April measurements (Fig. 2)

$$
T=-4.23+0.3^{8} y
$$

to represent temperature at $t=0$. Curve (c) in Figure 4 shows the solution of Equation (2) with numerical values appropriate to Athabasca Glacier: $T=-4.23^{\circ} \mathrm{C}, a=0.3^{8}$ deg $\mathrm{m}^{-1}$, length of ablation season $t=0.2 \mathrm{a}$, total ablation $v t=-3.8 \mathrm{~m}, k=36.3 \mathrm{~m}^{2} \mathrm{a}^{-1}$. It appears that, even when allowance is made for the ice removed by ablation, heat conduction is inadequate to warm all the ice to $0^{\circ} \mathrm{C}$ by the end of the ablation season. Thereafter, there is a net loss of heat from the surface so all the ice will never reach $0^{\circ} \mathrm{C}$.

Figure 4 includes curves for three additional cases to show the effect of variations in ablation rate and in length of ablation season; the variations are larger than those encountered from year to year on Athabasca Glacier. The curves illustrate the importance of the amount of ablation in determining the temperature distribution. The curves are easily converted to "cold waves" of different amplitudes; if $T_{0}$ and $a$ are each multiplied by $m$, the final temperatures are also.

\section{Percolation and refreezing of melt water}

Nye and Frank (in press) believe that, contrary to previous opinions (Steinemann, I958; Lliboutry, I964-5, Tom. I, p. I 1 2-3), pure polycrystalline ice at the melting point is permeable to water. Thus latent heat, released by percolating melt water when it refreezes on contact with a subfreezing layer, is a possible means of warming the ice in the ablation area. We now try to assess its importance.

On Nye and Frank's model (c.f. Frank, I 968), the ice is assumed to be at the pressure melting point throughout and the water flows downwards, under a pressure gradient due to the density difference between ice and water, through a network of veins between the ice grains. The situation considered here is somewhat different. At the end of summer, when 
the supply of melt water is cut off and the ice starts to lose heat, any water in the nearsurface ice will freeze and ice creep will start to close any air-filled veins or cavities. Thus, by the beginning of the following summer, the permeability of the near-surface ice should be almost zero. Thus, at each depth, melt water will have to penetrate from the surface, freeze and release latent heat to bring the surrounding ice to the melting point and open up channels, before water can proceed to greater depths. As the details of this process are not clear, we propose to treat it as a process of diffusion of water into a semi-infinite medium. At each depth, the water must reach a certain concentration before it can advance further; the concentration is such that the latent heat released by the water on freezing is just sufficient to warm the ice at that depth to $0^{\circ} \mathrm{C}$. We assume that the concentration of water at the surface remains constant and that its temperature is $0^{\circ} \mathrm{C}$. Hill ( 1928 ) has used the same mathematical model in another problem.

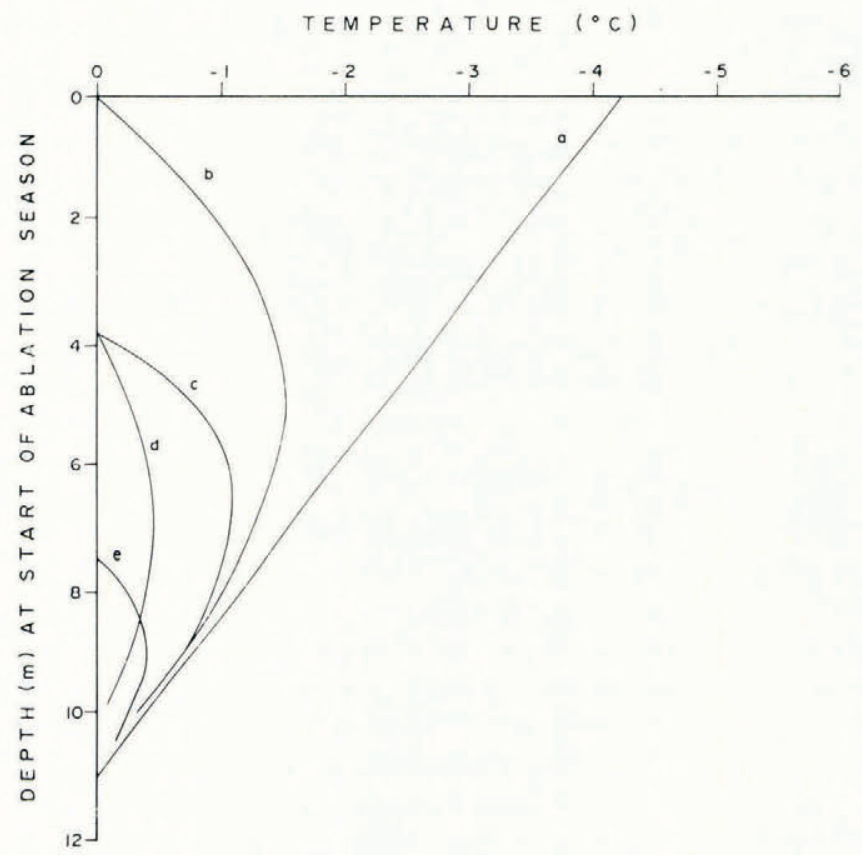

Fig. 4. Temperature profiles calculated from heat-conduction theory.
(a) Observed initial temperatures (see Fig. 2).
(b) Temperatures after 0.2 a with no ablation.
(c) After $3.8 \mathrm{~m}$ ablation in 0.2 a (average conditions in Athabasca Glacier).
(d) After $3.8 \mathrm{~m}$ ablation in $0.4 \mathrm{a}$.
(e) After $7.5 \mathrm{~m}$ ablation in $0.2 \mathrm{a}$.

Let $y$ denote distance below the surface, $t$ time, $f(y, t)$ volume of water per unit volume of ice, and $\lambda$ the volume concentration of water needed to raise the ice at depth $y$ to $\mathrm{o}^{\circ} \mathrm{C}$. Thus $\lambda=\rho c \Delta T / \rho^{\prime} L$ where $\rho$ and $\rho^{\prime}$ are densities of ice and water, $c$ specific heat of ice, $L$ its latent heat, and $\Delta T$ difference between ice temperature and $o^{\circ} \mathrm{C}$. Initially, $\Delta T$ and thus $\lambda$ are assumed to be the same at all depths. Let $Y(t)$ be the depth to which water has penetrated (the position of the $0^{\circ} \mathrm{C}$ isotherm) at time $t$. We wish to determine $Y(t)$ as a function of $\lambda$ and of $f_{0}$, the value of $f$ at the surface.

The diffusion equation is

$$
\partial f / \partial t=k \partial^{2} f / \partial y^{2}
$$


where $k$ is the diffusivity of water in ice. By using this equation we assume that the pressure gradient that makes the water flow downwards is not the dominant factor in determining the rate of penetration and therefore can be neglected. In addition, we assume that $k$ is constant above the $0^{\circ} \mathrm{C}$ isotherm and that $f_{0}$, the water concentration at the surface, is constant in time. These are dubious assumptions. At

Boundary conditions are:

For

At

$$
y=0, \quad f=f_{0} \text { for all } t \text {. }
$$

$$
t \rightarrow \infty, \quad f=f_{0} \text { for all } y \text {. }
$$

$$
y=Y(t), \quad f=0 .
$$

At $y=Y(t)$, the rate of diffusion of water must be equal to the rate at which water is being used to warm the ice. Thus

$$
-k(\partial f / \partial y)=\lambda(\mathrm{d} r / \mathrm{d} t)
$$

The solution of Equation (4) satisfying Conditions (5) and (6) is

Condition (7) then gives

$$
f=f_{0}-A \operatorname{erf}\left\{\frac{1}{2} y(k t)^{-\frac{1}{2}}\right\} \text {. }
$$

$$
Y=2 B(k t)^{\frac{1}{2}}
$$

where, from Condition (8), $B$ is given by

$$
B \operatorname{erf} B \exp B^{2}=f_{0} \lambda^{-1} \pi^{-\frac{1}{2}} .
$$

The value of $B$, for given $f_{0}$ and $\lambda$, can be determined from a table of $B \operatorname{erf} B \exp B^{2}$.

From Equation (9) one can calculate whether the water has reached the lower boundary of the cold layer by the end of the ablation season, when the surface water supply is cut off. The data required are $\lambda, f_{0}$, and $k$. From Equation (3), and appropriate values of the density and specific and latent heats of ice,

$$
\lambda=0.024-0.002 y, \quad \bar{\lambda}=0.014 .
$$

We take $f_{0}=0.01$. This is probably an upper limit. Nye and Frank (in press) consider that $f$ is unlikely to exceed o.oor. Joubert ( 1963 ) measured values from o.ooI 5 to o.or in ice in the Vallée Blanche. Ambach (1956) measured values up to 0.03 in Vernagtferner, but that was in ice within $160 \mathrm{~mm}$ of the surface where there is probably more water than at depth. Moreover, these measurements would include any water in isolated cavities as well as that in the vein system. There appear to exist no data on which to base an estimate of $k$ for ice. However, a value for firn can be obtained from the data of Hughes and Seligman ( 1939) who measured both temperatures and water percolation in the Jungfraufirn as functions of time. Application of the above theory to their data gives $k=185 \mathrm{~m}^{2} \mathrm{a}^{-1}$. For ice, it seems plausible to reduce this value by at least one order of magnitude and take $k=20$ $\mathrm{m}^{2} \mathrm{a}^{-1}$.

With the above values, Equation (9) becomes

$$
t=0.045 r^{2} \text {. }
$$

For $Y=10 \mathrm{~m}$ (minimum thickness of cold layer), $t=4.5 \mathrm{a}$. For $t=0.2 \mathrm{a}$ (length of ablation season), $Y=2.1 \mathrm{~m}$. A slightly more complex analysis in which $\lambda$ is allowed to vary linearly with depth gives similar values: for $Y=\mathrm{I} 0 \mathrm{~m}, t=2.6 \mathrm{a}$ and for $t=0.2 \mathrm{a}$, $r=2.1 \mathrm{~m}$. Thus the rate of melt-water penetration is less than the ablation rate. We conclude that refreezing of percolating melt water should be a negligible factor in warming the ice in the ablation area of Athabasca Glacier.

The foregoing theory is obviously much more elaborate than is warranted by existing data. The percolation of water through glacier ice needs detailed study. 


\section{Solar radiation}

Lliboutry (1964-5, Tom. I, p. 368) gives values of the extinction coefficient for solar radiation in glacier ice: $0.028 \mathrm{~mm}^{-1}$ at the surface, decreasing to $0.0018 \mathrm{~mm}^{-1}$ at depths below $0.2 \mathrm{~m}$. These figures imply that $50 \%$ of solar radiation is absorbed in the uppermost $30 \mathrm{~mm}$ and $99 \%$ in the first $\mathrm{r} .85 \mathrm{~m}$. In this case, solar radiation may be neglected as a means of warming the ice below the surface, although it is of course often the major factor in warming and melting the surface ice. However, Weller (1968) measured extinction coefficients of only $0.0013 \mathrm{~mm}^{-1}$ down to $\mathrm{I} \mathrm{m}$ and $0.0007 \mathrm{~mm}^{-1}$ below that depth in Antarctic "blue ice" and concluded that radiation was an important means of heat transfer even at a depth of $4 \mathrm{~m}$. Lliboutry's data appear to refer to conditions in the Alps in the ablation season and are therefore more appropriate for Athabasca Glacier than Weller's data from a region where the surface temperature was always below $0^{\circ} \mathrm{C}$. We conclude that solar radiation can probably be neglected in the case of Athabasca Glacier; but some measurements would be desirable.

\section{Discussion of measured temperatures}

Table II indicates that, on the plausible assumption that winter cooling does not penetrate below ro $\mathrm{m}$, the glacier is temperate in the accumulation area. Figure 3 shows that, in the ablation area, the ice had not attained the pressure melting temperature by the end of what was an exceptionally heavy ablation season. If the melting point has not been reached by the end of summer it never will be, because the ice then starts to lose heat again to the atmosphere. The data in Table II confirm that the ablation area is not temperate; all the ro-meter temperatures there, measured in three different years and at different times of year, are below $0^{\circ} \mathrm{C}$. Whether, at a given point, there are any measurable seasonal variations in Io-meter temperature is not known because thermistors were not left in the ice; fresh holes were drilled, usually at different locations, on each visit to the glacier. However, the Io-meter temperatures in holes $\mathrm{E}$ and $\mathrm{H}$ in April were close to that in hole $\mathrm{G}$, which is at about the same elevation, in the previous August. During the ablation season, because the surface level is changing, one might expect slight differences between temperatures measured at a depth of $\mathrm{I} 0 \mathrm{~m}$ at different times.

If hole $\mathrm{L}$ is excluded, the data in Table II show a slight trend for Io-meter temperature in the ablation area to decrease with increase of elevation (rate of about $0.3 \mathrm{deg}$ per $\mathrm{roo} \mathrm{m}$ ). Hole $\mathrm{L}$ was in moraine-covered ice near the valley walls. Hole $\mathrm{K}$ was also, and measurements there confirm that temperatures in this type of ice are lower than in the relatively clean ice in the central part of the glacier. Hole $\mathrm{K}$ only penetrated to $5.2 \mathrm{~m}$ but the temperatures there was $-\mathrm{I} .9^{\circ} \mathrm{C}$, the same as at that depth in hole L. Ablation of the moraine-covered ice is only about $60 \%$ of that elsewhere. Figure 4 illustrates how a decrease in the amount of ablation results in lower temperatures at depth. We suggest that this is the explanation of the observations. A contributing factor may be that, because the morainecovered ice stands relatively high, some snow may be removed by wind. Thus the accumulation there may be relatively low. This would increase the winter heat loss.

The observations thus confirm the conclusion, drawn from the preceding sections, that insufficient heat is supplied to the ice below the surface to bring it all to the melting point by the end of summer. The temperature profiles measured in September (Fig. 3) resemble those calculated from heat conduction theory (Fig. 4). Close quantitative agreement between theory and observation can hardly be expected, because the initial temperatures (Fig. 2) used in the calculations were measured at different places and in a different year from the final ones (Fig. 3). Moreover, the regression line is only a rough representation of the initial temperature. Perhaps the major discrepancy between Figures 3 and 4 is in the 
depth of minimum temperature. However, calculations show that the position of the minimum depends quite sensitively on the choice of initial temperature. We believe that inaccuracies in this can explain the discrepancy.

If penetration of melt water and solar radiation were significant means of heat transfer, the temperatures at the end of summer might still be calculated from heat-conduction theory, provided that a larger-than-normal value of thermal diffusivity were used. If increasing the value of diffusivity improved significantly the fit of the theoretical curves to the observations, this would suggest that the additional heat sources are not negligible. However, the limitations of the present data, mentioned above, preclude such a test.

\section{Discussion: Conditions for temperate ablation area}

Whether the near-surface layers in a glacier attain a temperature of $0^{\circ} \mathrm{C}$ by the end of summer depends both on the winter heat loss and the summer heat supply. The heat loss depends on such factors as winter air temperatures, extent of cloud cover, amount of snowfall and when it occurs. The preceding analyses indicate that ablation is the main factor in eliminating the winter "cold wave" in the ablation area. In other words, the heat that the surface receives from the atmosphere and from solar radiation is largely used to warm the surface ice to $0^{\circ} \mathrm{C}$ and then melt it. The sub-surface ice receives some heat by conduction. The longer the ablation season, the more effective conduction will be; but the amount of heat supplied in a typical season of two or three months is not large. (See Fig. 4.)

Thus we may speculate that few, if any glaciers are temperate throughout. Many glaciers appear to be temperate in the accumulation area. However most of these probably contain a region below the equilibrium line where, because ablation is small, some of the ice cooled in winter remains below the melting point throughout the following summer. In some glaciers this region of cold ice may extend to the terminus; in others, ablation at lower elevations may be sufficient to make the glacier temperate there. The critical value of ablation will of course depend on the extent of winter cooling.

Schytt (1969) has described this situation in Svalbard: "In many glaciers, previously considered as temperate, ... the cooling starts just above the equilibrium line and the ice temperature in the upper several tens of meters stays below $0^{\circ} \mathrm{C}$ all the way to the ice edge". Schytt's observation that the cold ice starts "just above" the equilibrium line has not been checked on Athabasca Glacier because the equilibrium line lies in an ice fall. However, hole $\mathrm{C}$, where the temperature is $0^{\circ} \mathrm{C}$, is a horizontal distance of only $600 \mathrm{~m}$ above the equilibrium line.

Vilesov (196I) measured temperatures at different times of year in the ablation area of Lednik Tsentral'nyy Tuyuksu in the Tien Shan. In comparison with Athabasca Glacier, the winter cooling is greater ( $\mathrm{I}$-meter temperature of $-6^{\circ} \mathrm{C}$ compared with $-4^{\circ} \mathrm{C}$ ) and ablation is less $\left(2 \mathrm{~m} \mathrm{a}^{-1}\right.$ against $\left.3.8 \mathrm{~m} \mathrm{a}^{-1}\right)$, although the ablation season is about the same length on both glaciers; thus the ro $\mathrm{m}$ temperature is lower $\left(-2.5^{\circ} \mathrm{C}\right.$ against $\left.-0.5^{\circ} \mathrm{C}\right)$.

Let us consider some other regions. In the European Alps, ablation exceeds ro $\mathrm{m} \mathrm{a} \mathrm{a}^{-1}$ on the lower parts of major glaciers such as Grosser Aletschgletscher (Kasser, [1956]) and Mer de Glace (Lliboutry and others, r962). But ice below the melting point might be found in the higher parts of the ablation areas of these glaciers, or in small glaciers whose termini are at relatively high elevations where ablation may be only 2 or $3 \mathrm{~m} \mathrm{a}^{-1}$. Blue Glacier, in north-western U.S.A., is temperate in the accumulation area; the temperature in the ablation area has not been measured (Shreve and Sharp, I970). As the maximum ablation is only $3.5 \mathrm{~m} \mathrm{a}^{-1}$ (LaChapelle, I965), one might expect that the ablation area would not be temperate. However, LaChapelle ( $196 \mathrm{I}$ ) found that, as a result of mild winters and heavy snowfalls, the temperature of the firn in the accumulation area hardly ever falls below $-2^{\circ} \mathrm{C}$ and that sub-freezing temperatures never penetrate below $4 \mathrm{~m}$. Conditions 
are probably similar in the ablation area. Moreover, the ablation season lasts 4 months, a relatively long period (LaChapelle, I965). In these circumstances, at least the lower part of the ablation area should be temperate.

The preceding discussion is oversimplified. Because accumulation and ablation vary over short distances as a result of variations in the nature and topography of the surface, thermal conditions will also vary. Figure 2, for example, illustrates how snow depth affects ice temperature. Again, the ice in the bed of a melt-water stream may be maintained at $\mathrm{O}^{\circ} \mathrm{C}$ throughout the summer, while ice on the crest of a hummock may be cooled by radiation every night; crevasses, moulins and melt streams influence the temperature of the surrounding ice; significant amounts of solar radiation may penetrate patches of bubblefree ice. Heat conduction will reduce such temperature inhomogeneities, but is unlikely to eliminate them. Perhaps, in some glaciers, conditions resemble those in regions of discontinuous permafrost, where patches of ground that thaw during summer are interspersed with patches that remain frozen. Moreover, ice temperature may vary from year to year as a result of climatic fluctuations. While seasonal variations are negligible at depths below about $10 \mathrm{~m}$, changes with longer periods are propagated to greater depths.

This paper, if it has done nothing else, should have pointed out the need for more temperature measurements in glaciers in temperate regions and also for detailed studies of the penetration of water and solar radiation into glacier ice.

\section{Acknowledgements}

Drs J. C. Savage and R. M. Koerner and Messrs C. S. L. Ommanney and D. Halyko helped in different stages of the field work. Mr W. Ruddy of Snowmobile Tours Ltd, Jasper, Alberta kindly provided transport of equipment on the glacier and also assisted in other ways.

Note. This paper was submitted before the publication of an important paper on the same general topic by Lliboutry ( I97I).

MS. received 12 March 1971 and in revised form 22 July 197 I

\section{REFERENGES}

Ahlmann, H. W. 1935. Contribution to the physics of glaciers. Geographical fournal, Vol. 86, No. 2, p. 97-1 13. Ambach, W. 1956. Zur Bestimmung des Luft- und Schmelzwassergehaltes des Gletschereises. Zeitschrift für Gletscherkunde und Glazialgeologie, Bd. 3, Ht. 3, p. 297-304.

Benfield, A. E. 195I. The temperature in an accumulating snowfield. Monthly Notices of the Royal Astronomical Society. Geophysical Supplement, Vol. 6, No. 3, p. 139-47.

Benfield, A. E. 1953. The effect of accumulation on temperatures within a snowfield. Journal of Glaciology,

Vol. 2, No. 14, P. $250-54$.
Carslaw, H. S., and Jaeger, J. C. 1959. Conduction of heat in solids. Second edition. Oxford, Clarendon Press.

Fisher, J. E. 1955. Internal temperatures of a cold glacier and conclusions therefrom. Fournal of Glaciology, Vol. 2, No. I8, p. $582-9$ I.

Fisher, J. E. 1963 . Two tunnels in cold ice at $4000 \mathrm{~m}$ on the Breithorn. Fournal of Glaciology, Vol. 4, No. 35, p. $513-20$.

Frank, F. C. I968. Two-component flow model for convection in the earth's upper mantle. Nature, Vol. 220,

No. $5^{165}$, p. $350-52$.
Hill, A. V. 1928 . The diffusion of oxygen and lactic acid through tissues. Proceedings of the Royal Society, Ser. B, Vol. 104, No. 728, p. 39-96.

Hughes, T. P., and Seligman, G. 1939. The temperature, melt water movement and density increase in the névé of an alpine glacier. Monthly Notices of the Royal Astronomical Society. Geophysical Supplement, Vol. 4, No. 8, p. $616-47$.

Joubert, J.-L. I963. Stratigraphie de la glace tempérée à l'aide de la teneur en eau liquide. Comptes Rendus Hebdomadaires des Séances de l'Académie des Sciences (Paris), Tom. 257, No. 23, p. 3638-39.

Kasser, P. [1956.] Sur le bilan hydrologique des bassins glaciaires avec application au grand glacier d'Aletsch. Union Géodésique et Géophysique Internationale. Association Internationale d'Hydrologie Scientifique. Assemblée générale de Rome 1954, Tom. 4, p. $33^{1-50}$. 
LaChapelle, E. R. 1961. Energy exchange measurements on the Blue Glacier, Washington. Union Géodésique et Géophysique Internationale. Association Internationale d'Hydrologie Scientifique. Assemblée générale de Helsinki, 25-76-3 1960. Commission des Neiges et Glaces, p. 302-10.

LaChapelle, E. R. ${ }^{9} 96_{5}$. The mass budget of Blue Glacier, Washington. Journal of Glaciology, Vol. 5, No. 41, p. $609-23$.

Lliboutry, L. A. 1964-65. Traité de glaciologie. Paris, Masson et Cie. 2 vols.

Lliboutry, L. A. r971. Permeability, brine content and temperature of temperate ice. Fournal of Glaciology, Vol. 10, No. 58, p. 15-29.

Lliboutry, L. A., and others. 1962. Étude de trois glaciers des Alpes Françaises, [par] L. [A.] Lliboutry, M. Vallon et R. Vivet. Union Géodésique et Géophysique Internationale. Association Internationale d'Hydrologie Scientifique. Commission des Neiges el des Glaces. Colloque d'Obergurgl, ro-9-13-9 1962, p. 145-59.

Loewe, F. 1966. The temperature of the Sukkertoppen ice cap. Fournal of Glaciology, Vol. 6, No. 43, p. 179. [Letter.]

McCall, J. G. 1952. The internal structure of a cirque glacier: report on studies of the englacial movements and temperatures. Fournal of Glaciology, Vol. 2, No. 12, p. 122-31.

Mathews, W. H. I964. Water pressure under a glacier. Fournal of Glaciology, Vol. 5, No. 38, p. $235-40$.

Miller, M. M. [1956.] Glaciothermal studies on the Taku Glacier, southeastern Alaska. Union Géodésique et Géophysique Internationale. Assemblée générale de Rome 19.54, Tom. 4, p. 309-27.

Nye, J. F., and Frank, F. C. In press. The hydrology of the intergranular veins in a temperate glacier. Union Géodésique et Géophysique Internationale. Association Internationale d'Hydrologie Scientifique. Commission de Neiges et Glaces. Symposium on the hydrology of glaciers, Cambridge, 7-13 September 1969, organized by the Glaciological Society.

Paterson, W. S. B. I969. The physics of glaciers. Oxford, etc., Pergamon Press. (The Commonwealth and International Library. Geophysics Division.)

Paterson, W. S. B., and Savage, J. C. 1963. Geometry and movement of the Athabasca Glacier. Fournal of Geophysical Research, Vol. 68, No. 15, p. 4513-20.

Paterson, W. S. B., and Savage, J. C. 1970. Excess pressure observed in a water-filled cavity in Athabasca Glacier, Canada. Journal of Glaciology, Vol. 9, No. 55, p. $103-07$.

Schytt, V. 1968. Notes on glaciological activities in Kebnekaise, Sweden, during r966 and 1967. Geografiska Annaler, Vol. 50A, No. 2, p. I I I-20.

Schytt, V. 1969. Some comments on glacier surges in eastern Svalbard. Canadian Journal of Earth Sciences, Vol. 6 , No. 4 , Pt. 2, p. $867-73$.

Sharp, R. P. 1951. Thermal regimen of firn on upper Seward Glacier, Yukon Territory, Canada. Fournal of Glaciology, Vol. I, No. 9, p. 476-87.

Shreve, R. L., and Sharp, R. P. I970. Internal deformation and thermal anomalies in lower Blue Glacier, Mount Olympus, Washington, U.S.A. Journal of Glaciology, Vol. 9, No. 55, p. $65-86$.

Steinemann, S. 1958. Thermodynamics and mechanics of ice at the melting point. Union Géodésique et Géophysique Internationale. Association Internationale d'Hydrologie Scientifique. Symposium de Chamonix, I6-24 sept. 1958, p. 254-65.

Sverdrup, H. U. 1935. The temperature of the firn on Isachsen's Plateau and general conclusions regarding the temperature of the glaciers on West Spitsbergen. Geografiska Annaler, Arg. 17, Ht. I-2, p. 53-88.

Vallot, J. r913. Valeur et variation de la température profonde du glacier, au Mont Blanc. Comptes Rendus Hebdomadaires des Séances de l'Académie des Sciences (Paris), Tom. I56, No. 20, p. I 575-78.

Vilesov, E. N. I961. Temperature of ice in the lower parts of the Tuyuksu glaciers. Union Géodesique et Géophysique Internationale. Association Internationale d'Hydrologie Scientifique. Assemblée générale de Helsinki, 25-7-6-8'196o. Commission des. Neiges et Glaces, p. 313-24.

Weller, G. 1968. The annual heat energy transfer above and inside Antarctic blue ice. Union de Géodésie et Géophysique Internationale. Association Internationale d'Hydrologie Scientifique. Assemblée générale de Berne, 25 sept.7 oct. 1967. [Commission des Neiges et Glaces.] Rapports et discussions, p. 417-28. 